\title{
Review
}

Medical Principles

and Practice

Received: December 8, 2009

DOI: $\underline{10.1159 / 000319544}$

Accepted: May 30, 2010

\section{Clinical Application of Proteomics \\ in Breast Cancer: State of the Art and Perspectives}

\author{
Anthony Goncalves ${ }^{a-c}$ François Bertucci $^{\mathrm{b}-\mathrm{d}}$ \\ ${ }^{a}$ Centre de Recherche en Cancérologie de Marseille, Département de Pharmacologie Moléculaire, \\ Institut Paoli-Calmettes et UMR599 Inserm, ${ }^{b}$ Département d'Oncologie Médicale, Institut Paoli-Calmettes, \\ ${ }^{C}$ Faculté de Médecine, Université de la Méditerranée, et ${ }^{d}$ Département d'Oncologie Moléculaire, \\ Institut Paoli-Calmettes, Marseille, France
}

\section{Key Words}

Breast cancer • Proteomics • Diagnosis • Prognosis •

Treatment

\begin{abstract}
Breast cancer is one of the most frequent and deadly cancers in industrialized countries. The identification of accurate biomarkers that improve the screening, diagnosis, prognostication and prediction of therapeutic response or toxicity, and the identification of novel molecular therapeutic targets are crucial. Today, high-throughput molecular techniques permit investigators to systematically interrogate the genome, transcriptome, and proteome of cancer cells. During the past decade, mRNA expression profiling has been successfully applied to the molecular characterization of breast cancers. Application of proteomics-based techniques is also considered crucial for detecting new biomarkers. In this review, we present the proteomics-based methods that have been applied to date to breast cancer samples for diagnostic and prognostic purposes. Despite their current limits, these pioneering techniques are promising. The most important results as well as the current limitations and perspectives are summarized and discussed.

Copyright $\odot 2010$ S. Karger AG, Basel
\end{abstract}

\section{Introduction}

Completion of the human genome project and technological progress are revolutionizing translational medicine. Today, high-throughput molecular technologies ('omics') permit investigators to systematically interrogate the genome, transcriptome and proteome of cancer cells. They provide real molecular portraits of biological samples, offering an unprecedented opportunity to discover new diagnostic, prognostic or therapeutic targets. Since the mid nineties of the last century, large-scale RNA expression profiling has been the most developed approach. In particular, DNA microarrays have been applied to clinical breast cancer samples [1], and have rapidly confirmed their potential clinical significance through the identification of biologically and clinically relevant molecular subtypes [luminal A and B, basal, human epidermal growth factor receptor 2 (HER2)-overexpressing, and normal-like] and of new prognostic subclasses, unidentifiable by conventional means [2]. Today, two prognostic gene expression signatures (Oncotype $\mathrm{DX}^{\circledR}$ and Mammaprint ${ }^{\circledR}$ ) derived from these studies are being tested in prospective phase III trials [3, 4], the ultimate phase before their diffusion into routine clinical practice [5].

\section{KARGER}

Fax +4161306 1234

E-Mail karger@karger.ch

www.karger.com
(C) 2010 S. Karger AG, Basel

1011-7571/11/0201-0004\$38.00/0

Accessible online at:

www.karger.com/mpp
Prof. François Bertucci, MD, $\mathrm{PhD}$

Département d'Oncologie Médicale, Institut Paoli-Calmettes

232, boulevard Ste-Marguerite

FR-13009 Marseille (France)

Tel. +33 491223 537, Fax +33 491223 670, E-Mail bertuccif@ marseille.fnclcc.fr 
Table 1. Proteomic tools applied to biomarker research in mammary oncology

\begin{tabular}{l} 
Non-MS-based \\
Tissue microarrays and immunochemistry \\
Protein arrays \\
Antibody microarrays \\
Reverse-phase protein arrays \\
MS-based \\
Protein separation tools \\
2D electrophoresis \\
Liquid chromatography \\
Protein-profiling tools \\
$\quad$ ProteinChips/SELDI-TOF MS (BioRad) \\
ClinProt/MALDI-TOF MS (Brucker) \\
Protein identification tools \\
MALDI-TOF MS \\
$\quad$ ESI-TOF MS \\
Q-TOF MS/MS \\
Ion trap MS/MS \\
Fourier transform MS \\
Protein quantification \\
SILAC \\
ICAT \\
iTRAQ \\
MS = Mass spectrometry; SELDI-TOF = surface-enhanced la- \\
ser desorption ionization-time of flight; MALDI-TOF = matrix- \\
assisted laser desorption ionization-time of flight; ESI-TOF = \\
electrospray ionization-time of flight; Q-TOF = quadruple time \\
of flight; MS/MS = tandem mass spectrometry; SILAC = stable \\
isotope labeling with amino acids in cell culture; ICAT = isotope- \\
coded affinity tag; iTRAQ = isotope tagging for relative and ab- \\
solute quantification. \\
\hline
\end{tabular}

\section{Non-MS-based}

Antibody microarrays

MS-based

otein separation tools

$2 \mathrm{D}$ electrophoresis

tein-profiling tools

ProteinChips/SELDI-TOF MS (BioRad)

on trap MS/MS

SILAC

ICAT

ser desorption ionization-time of flight; $\mathrm{MAIDI-TOF}=$ matrixassisted laser desorption ionization-time of flight; ESI-TOF = isotope labeling with amino acids in cell culture; ICAT = isotopesolute quantification.

In this 'omics context', proteomics represents one of the latest technological developments. Similar to studies aimed at deciphering transcriptional changes important in cancer, proteomic approaches allow global and comparative studies of proteins to be performed on normal and pathological samples. Proteomics has the potential to complement the information generated by genomics for several reasons. mRNA levels do not necessarily correlate with the abundance of the corresponding protein [6-8]; additional complexity of proteins is conferred by posttranslational modifications such as phosphorylation, acetylation, and glycosylation, or protein cleavage, which are not detectable at the mRNA level, but play significant roles in protein functions [9]; since proteins bridge the gap between RNA and cellular physiology, their potential as clinically relevant biomarkers is theoretically superior; finally, proteins represent more accessible and relevant therapeutic targets than nucleic acids. Many recent technical advances in mass spectrometry (MS) and microarrays have enabled high-throughput proteome analysis.

In this review, we describe the proteomics-based methods that have been applied to date to clinical breast cancer samples for diagnostic and prognostic purposes. These studies were performed on tumor tissues and biological fluids. The most important results as well as the current limitations and perspectives are summarized and discussed. For reasons of space, we will not address the issues of tissue microarrays and immunohistochemistry, which are exhaustively described elsewhere [10].

The proteomic technologies (table 1) may be roughly distinguished according to the use or not of MS. Typically, non-MS-based approaches correspond to microarray-based techniques, and require a priori hypotheses or selection of proteins to be tested, whereas MS-based techniques do not require any previous biological foreknowledge, and allow examination and quantification of a large number of initially unknown protein parameters. However, some MS-based approaches may also be hypothesis based (e.g. immunoprecipitation MS), and an alternative distinction can separate methods as candidate-based or non-candidate-based methods. Candidate-based methods require antibodies or other affinity reagents against specific candidates, whereas non-candidate-based methods are typical screening approaches.

\section{Protein Arrays}

As protein probes are arrayed on solid supports and their specific interactions with proteins present in complex biological samples tested, protein arrays are theoretic protein counterparts of DNA microarrays [11]. In antibody microarrays, one of the most developed formats, spotted specific antibodies are confronted with samples along with various labeling and detection systems. Technological limitations include the availability of antibodies, the space available on the array, and the fact that the recommended experimental conditions may not be optimal for all arrayed antibodies, which have specific affinities for their ligand. Biological fluids such as serum or plasma as well as tumor tissue itself can be analyzed. For example, the expression of 378 proteins was measured in matched malignant and adjacent normal breast tissues using antibody microarrays [12]. The authors found increased expression levels of various proteins, such as casein kinase $\mathrm{I} \varepsilon, \mathrm{p} 53$, annexin XI, CDC25C, eIF-4E and MAP kinase 7, in malignant breast tissues, 
whereas the expression of other proteins, such as the multifunctional regulator $14-3-3 e$, was decreased. Importantly, the results were confirmed by immunohistochemistry, indicating the reliability of the process.

Antibody microarrays may be specifically designed to evaluate particular biological processes, such as cytokine expression. This was used in cell line models, but also in serum or tumor tissue from breast cancer patients [1316]. For example, cy tokine expression levels were screened in culture medium from breast cancer cell lines [15], identifying interleukin 8 as a factor related to estrogen receptor status and metastatic potential. A similar approach applied to MCF7 cells overexpressing HER2 or not generated a 'HER2-induced cytokine' signature including CXCL8 (interleukin 8), CXCL1 and growth-related oncogenes. Interestingly, the latter were also found to be upregulated in sera from HER2-positive metastatic breast cancer patients [16]. Recently, a large-scale (129 analytes) recombinant $\mathrm{scFv}$ cytokine-based antibody microarray was used in an attempt to classify patients with metastatic breast cancers versus healthy controls based on differential protein expression profiling of whole serum samples. Breast cancers could be classified with $85 \%$ specificity and sensitivity. By adopting a condensed signature composed of the top 9 differentially expressed proteins, the authors [17] distinguished cancer from healthy serum proteomes with $95 \%$ sensitivity and specificity.

Instead of planar-based multiplexing, bead-based multiplexing may be used. In Luminex systems (Luminex Corp., Austin, Tex., USA), different fluorescent and spectrally resolvable beads coated with distinct antibodies to various cytokines, such as interleukins, interferons, granulocyte colony-stimulating factor and tumor necrosis factor, are incubated with a biological sample. The mixture is then incubated with a mixture of detection antibodies, each corresponding to one of the capture antibodies. The detection antibodies are tagged for detection of fluorescence. The beads are passed through a flow cytometer, and each bead is detected by two lasers: one for the identity of the bead and the other for the amount of antibody on the bead [18]. Applications in breast cancer have included cytokine profiling on serum with attempts to distinguish patients with breast cancer from healthy women and node-negative from node-positive patients as well as generating a cytokine signature of HER2-based vaccination [19]. This technology was also applied to serum samples from patients enrolled in a phase I-II study of liposomal doxorubicin and paclitaxel in combination with whole breast hyperthermia for the neoadjuvant treatment of locally advanced breast cancer [20]. When
27 patients achieving pathological complete or partial responses were compared with 16 patients demonstrating no response, serum levels of epidermal growth factor receptor (EGFR), soluble Fas ligand, migration inhibitory factor and matrix metalloproteinase-2 levels were shown to be higher in responders than in nonresponders. Logistic regression analysis identified a 5-biomarker panel consisting of HER2, EGFR, migration inhibitory factor, matrix metalloproteinase- 2 and CD40 ligand that could distinguish responders from nonresponders with $85 \%$ sensitivity and $69 \%$ specificity. In another study, serum samples from 98 breast cancer patients and 96 normal subjects were incubated with an antibody-bead array of 35 markers constructed using the Luminex bead array platform [21]. Serum concentrations of EGF, soluble CD40 ligand and proapolipoprotein A1 levels were increased in breast cancer patients, whereas high-molecular-weight kininogen, apolipoprotein $\mathrm{A}_{1}$, soluble vascular cell adhesion molecule-1, plasminogen activator inhibitor-1, vitamin D-binding protein and vitronectin were decreased. Multivariate classification algorithms distinguished breast cancer patients from the normal population with high accuracy (87.6-91.8\% depending on the algorithm). Similar performances were reported for an independent validation set of 169 samples. Correlations were also found between the expression of various cytokines and clinicopathological parameters of breast cancer.

Reverse-phase protein array (RPPA) technology is a complementary approach to antibody microarrays. The basis of the technology is to immobilize small amounts of lysate from cell lines or tumor samples in serial dilutions on a microarray slide. Multiple samples are thus arrayed on a slide and can be probed with antibodies that detect particular epitopes, including phosphorylated regions. Subsequently, labeled secondary antibodies are applied and analyzed with a detection/amplification system [22]. Thus, several samples and the activation state of various members of a given intracellular pathway may be examined in a single experiment [23]. However, in contrast to tissue microarrays, it is difficult, using RPPA, to characterize the subcellular location of proteins whose expression is being measured even though subcellular fractionation may be performed prior to binding arrays. Boyd et al. [24] used RPPA to examine the phosphorylation status of 100 proteins in 30 breast cancer cell lines that had previously been characterized at the transcriptional level. The technology was demonstrated to be analytically reproducible (Pearson correlation, $r=0.94$, between independently derived lysates from the same cell 
line) and specific pathway activation events were identified in the different molecular subtypes of breast cancer. For example, basal-like cells had low levels of pPTEN and high levels of total EGFR, Pyk2 $\left(\mathrm{Y}^{402}\right)$ and PKC- $\alpha\left(\mathrm{S}^{567}\right)$; luminal-like cells had higher levels of phosphorylation of pp70S6K $\left(S^{371}\right)$ and pA-RAF $\left(S^{299}\right)$, and HER2-amplified cells had high levels of pERBB3, pFAK and pEGFR $\left(\mathrm{Y}^{1173}\right)$. Importantly, the pretreatment levels of specific phosphorylated proteins correlated with in vitro response to potent and selective PI3K and MEK inhibitors. For example, a correlation existed between sensitivity to MEK inhibitors and total EGFR and phosphorylated ERK1/2 (the direct targets of MEK phosphorylation) expression, suggesting that constitutive signaling via the EGFR/RAS/ MEK/ERK axis may constitute a positive predictive factor for MEK inhibition. Conversely, phosphorylation of components of Akt and mTOR signaling such as PDK1 and p70S6K was negatively associated with response. In contrast, sensitivity to the PI3K/mTor inhibitor PI-103 was correlated with elevated phosphorylation at key nodes in the PI3K/AkT/mTOR pathway, including pAkt $\left(\mathrm{T}^{308}\right.$ and $\left.\mathrm{S}^{473}\right)$, PRAS40 $\left(\mathrm{T}^{246}\right)$ and FKHR $\left(\mathrm{T}^{24}\right)$, suggesting that high levels of signaling via the pathway may be indicative of pathway addiction and predictive of response to a targeted PI3K inhibitor. RPPA has also been applied to breast cancers whose PIK3CA mutational status and PTEN protein expression level were measured [25]. As expected, AkT phosphorylation at $\mathrm{Thr}^{308}$ and $\mathrm{Ser}^{473}$ was present at higher levels in low-PTEN compared with high-PTEN tumors, as was mTOR and p70S6K phosphorylation. There were no significant differences in AkT, GSK3, mTOR or p70S6K phosphorylation between mutant PIK3CA versus wild-type PIK3CA tumors, suggesting that PTEN loss and PIK3CA mutations have markedly different functional effects on the PI3K pathway in breast cancer. Of note, the interactome of AkT has also been described using MS-based proteomic technologies [26, 27].

In another study [28], RPPA has been used to evaluate the protein expression of cyclins B1, D1 and E1 in a series of breast cancers in parallel with other technologies, such as immunohistochemistry (estrogen receptor, progesterone receptor, HER2), FISH (HER2), transcriptional profiling (molecular subtypes), gene copy number by array comparative genomic hybridization and mutational status (PIK3CA, P53). The expression levels of cyclins B1, D1 and E1 were differentially altered in the different subtypes, suggesting distinct roles according to the subtype. Cyclin B1 was the cyclin most strongly associated with poor prognosis in patients with hormone receptor-posi- tive tumors. Its gene expression was correlated with that of PLK, CENPE, and AURKB, which encode proteins targeted by drugs under development that may be of particular interest in the treatment of these tumors.

\section{MS-Based Approaches}

In contrast to microarray-based approaches, the MSbased technologies are exempt of a priori assumptions, i.e. they do not require any biological foreknowledge, and permit the examination and quantification of a large number of initially unknown protein parameters.

After appropriate extraction and separation of proteins from given biological samples, MS-based approaches may be used in two complementary ways in order to identify clinically relevant biomarkers: (1) actual protein quantification and identification by increasingly sophisticated MS, and (2) protein profiling to generate a multiprotein signature. These technologies are still beset by significant limitations, such as overall sensitivity, reproducibility in a high-throughput context and difficult access to the lowabundance proteome; however, in contrast to protein arrays, they are not limited by the necessity of a priori biological knowledge and, therefore, have the potential to discover previously unrecognized protein biomarkers.

\section{MS-Based Protein Identification and Quantification}

Here MS is used to actually identify peptides and/or proteins, either intact or after enzymatic digestion, in a sample. In matrix-assisted laser desorption ionizationbased (MALDI) MS (MALDI-MS), ionized peptides are generated from samples in a solid phase (after cocrystallization with a chemical matrix), whereas in electrospray ionization (ESI)-based MS, ionized peptides are produced from a liquid phase and are sprayed as highly charged thin droplets. Thereafter, MALDI- and ESI-generated peptides are classically analyzed by measurement of their time-of-flight (TOF-based MS), which is tightly correlated with their mass (mass to charge or $\mathrm{m} / \mathrm{z}$ ratio) $[29,30]$. Most frequently, MS analysis is applied to samples following enzymatic digestion (bottom-up proteomics), and protein identities may be obtained in two ways: (1) peptide mass fingerprint, where experimentally measured masses are compared with theoretical masses in the protein databases, and (2) tandem MS (MS/MS) sequencing, where ionized, digested and MS-measured peptides are then subsequently picked up for a fragmentation step and a second MS-based measurement, providing almost complete peptide sequences [31]. 


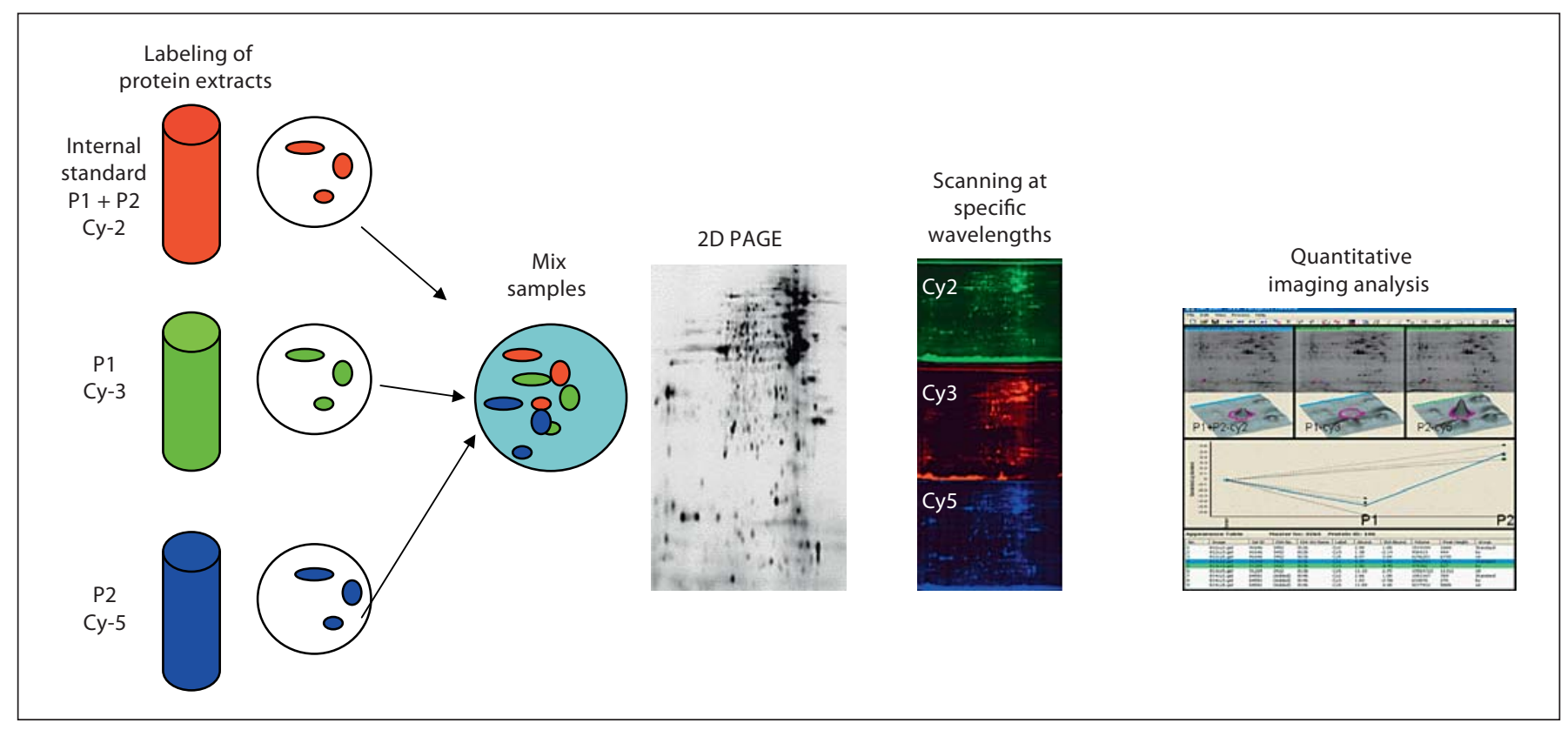

Fig. 1. Principles of two-dimensional differential gel electrophoresis. Samples to be compared (P1 and $\mathrm{P} 2$ ) are labeled by fluorescent dyes (Cy-3 and $\mathrm{Cy}-5)$ with affinity for lysine amino acids and mixed with an internal standard (Cy-2). These probes have the same mass and charges, but are spectrally discernable. The mix is subjected to isoelectrofocusing and sodium dodecyl sulfate polyacrylamide gel electrophoresis. The gel is then analyzed in a laseractivated fluorescence scanner at the excitation wavelength of each dye, thus allowing simultaneous detection of the major components in these two proteomes.
In both cases, a protein separation step is necessary before identification. The most famous separation procedure is two-dimensional polyacrylamide gel electrophoresis (2D-PAGE), which allows the simultaneous study of up to several thousands of proteins on a single gel. In $2 \mathrm{D}$ PAGE, extracted proteins are first separated according to their isoelectric point ( $\mathrm{pH}$ gradient) and then according to their mass (sodium dodecyl sulfate polyacrylamide gel electrophoresis) [32]. A large number of 2D-PAGE-based procedures have been applied to preclinical models of breast cancer, but relatively few data have been generated from clinical samples, essentially comparing in situ or invasive breast cancers to normal tissues [33-42] or analyzing biological fluids $[43,44]$. Recently, 77 adenocarcinomas from different primary sites, including 9 breast cancers, were analyzed [45]. Some tumor site-specific proteins were identified by MS/MS and contributed to the construction of an algorithm allowing discrimination of the distinct primaries. Niméus et al. [46], using 2DPAGE, identified differentially expressed proteins according to the presence or absence of a metastatic relapse in 20 patients with node-positive early breast cancer after adjuvant chemotherapy with cyclophosphamide, methotrexate and fluorouracil. Another study compared the proteome extracted from primary cultures of epithelial cells obtained from 23 surgically resected breast cancers with or without subsequent metastatic relapse [47]. Three protein spots differed between the metastatic and nonmetastatic groups and were identified by ESI-MS/MS. Nucleophosmin was increased in the group with metastases, whereas 2,3-trans-enoyl-CoA isomerase and glutathione peroxidase 1 were decreased. 2D-PAGE was also used to compare 13 pairs of matched primary breast cancers and axillary lymph node metastases [48]. The quantification of 135 well-resolved and MALDI-TOF MSidentified proteins revealed striking similarities in their overall expression patterns, although distinct changes in the levels of individual proteins were also observed in some sample pairs. In this study, a similar comparison was performed at the genomic level using array comparative genomic hybridization and confirmed high similarities between the matched primary tumors and the lymph node metastases. These data suggested that key biological characteristics of the primary breast tumor are maintained in the corresponding lymph node metastases.

Although still being considered as a major procedure, 2D-PAGE has limited usefulness for analysis of extremerange molecular weights or $\mathrm{pHs}$ as well as hydrophobic or 
low-abundance proteins. Its major disadvantage lies in its low reproducibility and limited high-throughput capability. To improve the sensitivity, reproducibility and rapidity of conventional 2D-PAGE, two-dimensional differential gel electrophoresis was introduced [49]. Here protein extracts are first labeled by fluorochromes (cyanines: $\mathrm{Cy} 2, \mathrm{Cy} 3$ or $\mathrm{Cy} 5$ ), then identical amounts of the samples to be compared are mixed and simultaneously resolved by $2 \mathrm{D}-\mathrm{PAGE}$. The pattern of migration is then visualized by a fluorescence imager after exciting the gel using 2 specific wavelengths (Cy2 and $\mathrm{Cy} 3$ specific). Images are analyzed and each spot is quantitatively compared between samples (fig. 1). This procedure drastically reduces the intergel variability that may be observed with 2D-PAGE and improves the accuracy of the quantification. This approach was recently applied to breast cancer cells derived from micrometastasis and revealed a stem cell protein profile [50].

Liquid chromatography (LC), where peptides in solution are injected through chromatographic columns, represents an alternative to $2 \mathrm{D}$-PAGE for separating proteins. Retained species are dependent on the chromatographic properties of the column; they are then eluted and evaluated by MS instruments thereafter [29]. For example, a conventional high-performance liquid chromatography (HPLC) procedure was coupled to MALDI-MS to identify differentially expressed peptides from estrogen receptor-positive $(n=39)$ and estrogen receptor-negative $(\mathrm{n}=41)$ invasive breast cancers [51]. In addition, HPLC may include several sequential steps of complementary chromatographic procedures, as in multidimensional protein identification technology [52]. Two steps of HPLC (cation exchange and reverse phase) are coupled to MS/MS and database-searching algorithms and allow rapid analysis of complex mixtures with direct identification of the generated peptide sequences. This technique has recently been associated with enzyme activity profiling in human breast tumors for generating functional signatures associated with the molecular subtypes [53].

To improve the quantitative capabilities and reproducibility of MS-based procedures, labeling-based technologies have recently been proposed, i.e. isotope-coded affinity tag (ICAT), stable isotope labeling with amino acids in cell culture (SILAC) and isotope tagging for relative and absolute quantification (iTRAQ). In ICAT-based technology, paired complex protein samples are isotopelabeled with tags, e.g. ${ }^{12} \mathrm{C}$ (light) and ${ }^{13} \mathrm{C}$ (heavy) that covalently bind to cysteine residues. Then samples are mixed, digested with trypsin, separated by HPLC and identified by MS. The tags used are similar in structure and chemical properties, but are different in mass. ICAT profiles the relative amounts of cysteine-containing peptides derived from tryptic digests of paired protein extracts [54]. This method was used for comparing the proteome of nipple aspirate fluids from cancerous breast tissues and from noncancerous contralateral breast tissues [55].

In the SILAC procedure, cells to be compared are metabolically labeled during the culture phase using supplementation of their medium with distinct isotopic forms of the same amino acids, i.e. 'heavy' (for example, arginine and lysine ${ }^{13} \mathrm{C}_{6}$ ) or 'light' (arginine and lysine ${ }^{12} \mathrm{C}_{6}$ ) forms. After labeling, cell lysates are mixed and subjected to LC-MS/MS. Peptides with incorporated heavy arginine and/or heavy lysine have a 6-Da higher mass of per amino acid relative to peptides with light isotopic arginine and/or lysine. The intensity ratios of the heavy and light peptide peaks, respectively, in a given mass spectrum indicate the relative abundance of proteins in both cell types. This approach was used to compare two isogenic human breast cancer cell lines that are equally tumorigenic in mice, but with very different metastatic capacities [56]. Following membrane purification, a SILACbased comparative quantitative LC-MS/MS proteomics approach identified 13 overexpressed and 3 underexpressed membrane proteins in the metastatic versus nonmetastatic cell line among a total of 1,919 identified protein entries. These results were validated by flow cytometry, Western blotting, and immunocyto- and immunohistochemistry. Analysis of clinical breast cancer biopsies demonstrated a correlation between high expression of some of these proteins (ecto-5'-nucleotidase and integrin $\beta 1$ ) and poor outcome.

The iTRAQ approach involves labeling of the primary amines of tryptic peptides with tags of varying mass. The samples to be compared are then pooled and usually fractionated by nano-LC and analyzed by MS/MS. This approach offers a robust and reproducible means for simultaneous identification and quantification of all peptides, including those with posttranslational modifications. This approach possesses the key advantage of enabling simultaneous analysis of up to 8 different biological specimens thereby increasing the analysis throughput while reducing experimental errors. Additionally, the resulting fragmented peptide product ions subjected to MS/MS are indistinguishable for the same protein originating from the different biological specimens. This leads to an improved signal-to-noise mass-spectral response for the peptide precursor (MS) and product (MS/MS) ions leading to more confident peptide identification, to an extent 
not feasible with ICAT or SILAC. The relative quantification is achieved via the differences in the abundances of the reporter product ions (i.e. $\mathrm{m} / \mathrm{z}$ ratio $114,115,116,117$ ) [57]. The iTRAQ approach has been applied in various studies, including the study of phosphoproteomic changes during breast cancer development [58]. Recently, iTRAQ was used to compare 3 human breast cancer samples with distinct metastatic phenotypes (2 primary breast tumors associated with metastatic lymph nodes or not, and 1 lymph node metastasis). The study resulted in the reproducible identification of 605 nonredundant proteins [59]. A quantitative comparison revealed 6 proteins with altered levels in metastatic versus nonmetastatic primary tumors and 19 proteins with altered levels in lymph node metastasis compared to nonmetastatic primary tumors. Changes in selected differentially expressed proteins were validated using real-time quantitative reverse transcription polymerase chain reaction.

Recently, there have been marked improvements in MS performance owing to improved instrumental design, such as ion trap [60], quadruple TOF or Fourier transform ion cyclotron resonance MS [61]. These more accurate and sensitive systems are expected to identify a significantly larger fraction of the proteome as compared with the conventional techniques and thus should become increasingly used for protein biomarker discovery. In addition, they may allow the analysis and accurate protein identification from entire proteins (top-down proteomics) without initial proteolytic digestion. A recent study used nano-LC coupled with Fourier transform ion cyclotron resonance MS to compare proteomes from recurrent breast tumors with distinct sensitivity to tamoxifen [62]. Analysis was performed on 25,000 pooled tumor cells obtained by laser capture microdissection from two independently processed data sets $(n=24$ and $n=27)$ containing both tamoxifen-sensitive and tamoxifenresistant tumors. A total of 17,263 unique peptides were identified, corresponding to 2,556 nonredundant proteins identified with more than 2 peptides. The 1,713 proteins common to the 2 data sets were selected for further analysis. Comparative analysis revealed 100 proteins differentially abundant between tamoxifen-sensitive and tamoxifen-resistant tumors, 47 of which were further verified by targeted LC-MS/MS on an independent data set. The most differentially expressed protein, extracellular matrix metalloproteinase inducer, was also validated using immunohistochemistry on tissue microarrays in an independent cohort $(n=156)$ with expression associated with a shorter time to progression on tamoxifen.
However, the major part of these achievements concerns higher sensitivity, resolution and mass accuracy, but the procedures still require very significant preanalytical work, which needs to be accommodated to the high-throughput setting often required in biomarker discovery. In addition, these very accurate techniques are not necessarily the most powerful in terms of quantification and may require additional external or internal additives to allow effective, reliable and reproducible quantitative comparisons between large numbers of clinical samples.

\section{SELDI- and MALDI-Based Protein Profiling of Clinical Samples}

MS-based approaches are also used as protein-profiling tools, before the actual identification of relevant proteins. Here biological samples (whole or fractionated) are, more or less directly, separated by miniaturized chromatography and subjected to TOF-based MS, generating for each sample a large list of protein peaks that are analyzed in terms of correlation with a clinically or biologically relevant phenotype.

Thanks to the relative simplicity of sample preparation, high analytical sensitivity and speed of data acquisition, surface-enhanced laser desorption/ionization (SELDI)-TOF MS, a variant of MALDI-TOF MS, was developed especially for clinical purposes [63]. In the SELDI procedure, biological samples (e.g. serum or tissue lysate) are cocrystallized with an energy-absorbing matrix on a solid support, comprised of various chromatographic surfaces, enabling an active role in sample fractionation. Subsequent irradiation with brief laser pulses sublimates and ionizes the proteins out of their crystalline matrix. Then the charged proteins migrate in an electric field to the TOF mass analyzer. Herein proteins are separated based on their mass, as the time to detector impact is proportional to the protein mass per charge. An adaptation of the SELDI concept has been recently proposed as well; it associates derivatized magnetic bead surfaces to conventional MALDI-TOF MS instruments. Like SELDI planar surfaces, these beads can be derivatized with multiple chemical affinity properties or biological capture components such as antibodies.

From a given biological sample, both technologies enable us to generate a protein profile composed of a list of protein peaks that are characterized by their masses and their relative intensities. Mass spectra are then processed by bioinformatic algorithms and analyzed using univariate and multivariate biostatistical tools to yield a singlemarker or a multimarker protein profile that can accu- 
rately classify samples. Combining different chromatographies, both technologies enable detection of up to 2,000 protein species in serum $[64,65]$. However, formal protein identification requires appropriate purification and subsequent protein identification using the MS-based tools described in the previous section.

SELDI- or MALDI-based protein profiling studies were carried out in oncology and applied to both tumor tissues and biological fluids, especially serum and plasma [65-71]. Indeed, since whole blood is considered to provide a dynamic reflection of physiological and pathological status, human plasma and serum represent the most extensively studied biological matrices in the quest for cancer biomarkers. Constantly perfusing the human body, the blood compartment constitutes a rich archive of proteins. Besides the expected circulatory proteins, this archive also contains specific tumor-secreted proteins, normal tissue and plasma proteins digested by tumor-secreted proteases, and proteins produced by local and distant responses to the tumor. Moreover, whole blood is an easy-to-sample and readily accessible matrix that allows repeated collection and analysis of large series.

In breast cancer, SELDI-TOF MS was used to investigate serum/plasma, nipple aspirate fluids and tumor tissues as a potential source for diagnostic, prognostic or predictive biomarkers. Some studies searched for serum biomarkers that differentiate breast cancer patients from those with benign disease and/or healthy subjects [72, 73]. Enrolling between 133 and 356 patients, these studies have identified diagnostic protein profiles with sensitivities and specificities of $76-96 \%$ and $85-93 \%$, respectively. While attempts at independent validation failed for some of them [74, 75], one study [76] reported excellent performance of a 7-peak classifier (not structurally identified) in an independent validation set analyzed 14 months after the initial identification. In addition, 2 previously identified biomarkers (8.1 and 8.9) [77] were further validated in an independent cohort, and identified by MS/ MS, as complement component $\mathrm{C} 3 \mathrm{a}_{\text {desArg }}$ and a C-terminal-truncated form of $\mathrm{C} 3 \mathrm{a}_{\text {desArg. }}$. Another 4.3-fragment, identified as inter- $\alpha$-inhibitor heavy chain 4 (ITIH4) fragment, was not validated. This fragment had been found to be increased in breast cancer [78], while similar ITIH4 fragments were found to be either increased [79] or devoid of discriminative power [80]. Given the inconsistent regulation observed across multiple studies, the definitive value of the different ITIH4 fragments, $\mathrm{C} 3 \mathrm{a}_{\text {desArg }}$, and C3 $\mathrm{a}_{\text {desArgD8 }}$ in the diagnosis of breast cancer cannot be determined yet. SELDI has been applied to plasma from HER2-positive breast cancer patients and control patients [81]; a set of 7 biomarkers distinguished disease from healthy samples, and was validated in an independent data set. Another serum-based study with diagnostic purpose [82] compared serum samples from patients with BRCA1 mutations who either developed cancer $(\mathrm{n}=15)$ or remained cancer-free $(\mathrm{n}=15)$. It revealed 23 markers associated with specimens with $B R C A 1$ mutations that classified the 2 groups with $87 \%$ sensitivity and specificity. This study also compared the serum profiles of patients with BRCA1-mutated cancer and with sporadic breast cancer. Various proteins were upregulated in the BRCA1 specimens and classified the 2 groups with $94 \%$ sensitivity and $100 \%$ specificity. However, no protein identity was reported, and the limited sample size precluded independent validation. Serum- and plasmabased diagnostic studies by SELDI-TOF MS have yielded numerous protein peaks with significantly different expression between breast cancers and healthy controls. However, although elucidation of protein identity is essential for insights into the pathophysiology of disease, so far, only a small percentage of reported peaks has been structurally identified. Moreover, since most studies did not investigate other cancer types or patients with benign breast disease, the specificity of the reported markers for breast cancer remains to be established. Furthermore, although of pivotal importance, only a few potential markers have been validated in independent sample sets. As these studies generally yielded contradictory results, further research is needed to determine the actual potential of identified markers in breast cancer diagnosis [83].

Serum-based protein profiling was also investigated as a prognostic tool, aiming to predict patient outcome following a given treatment. We retrospectively analyzed postoperative serum samples from 81 early breast cancer patients receiving postoperative anthracycline-based chemotherapy [84]. Proteins differentially expressed according to metastatic outcome were selected, from which combined supervised partial least-squares projection and logistic regression analysis generated a 40 -protein model that correctly predicted the clinical outcome in $83 \%$ of patients and identified 2 classes with different survival. This model was validated using leave-one-out cross-validation. Some of its components were identified: haptoglobin- $\alpha_{1}$ and transferrin levels were upregulated, whereas C3a complement fraction was downregulated in serum from patients with a high probability of relapse. All these proteins are not tumor specific and likely derive from host response. However, some of them are involved in biological processes such as angiogenesis and immune 


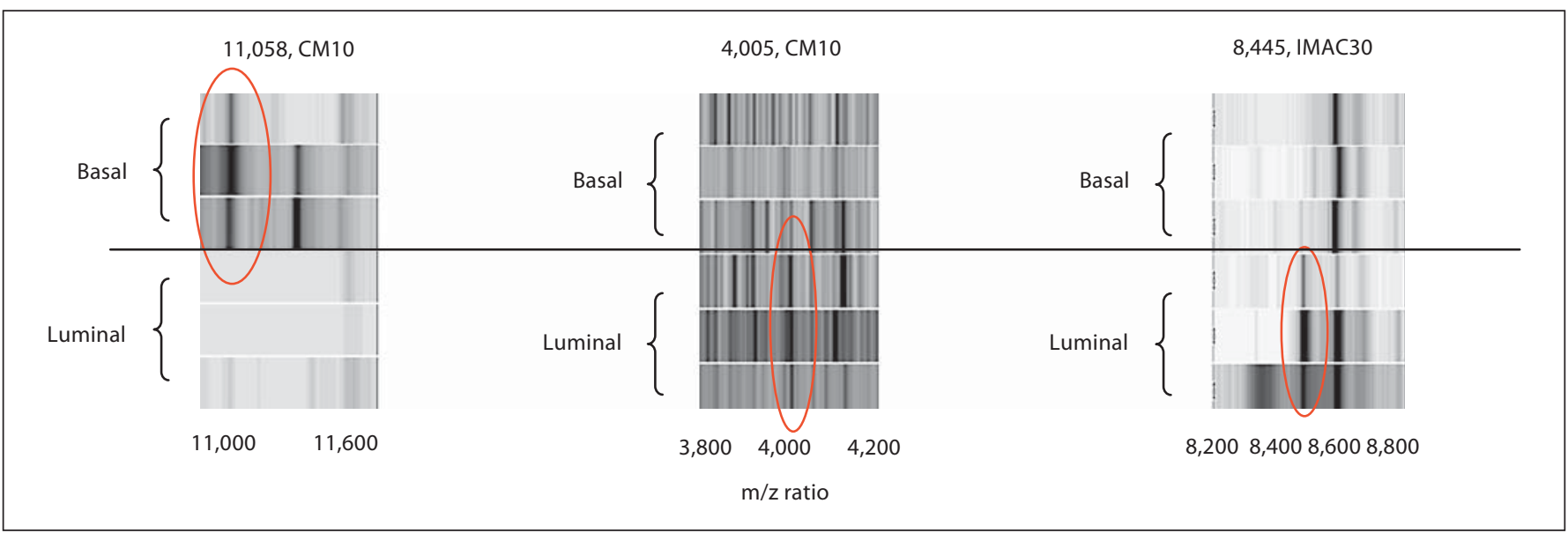

Fig. 2. SELDI-detected protein peaks with differential expression between luminal and basal breast cancer cells. Protein lysates from 27 human breast cancer cells were profiled using ProteinChip arrays CM10 and IMAC-Cooper, and analyzed with a SELDI platform. Protein peaks with various $\mathrm{m} / \mathrm{z}$ ratios were found

response, and are known to influence the metastastic risk. However, these results still require independent validation and must be considered as exploratory. A recent similar study [85] found the haptoglobin- $\alpha_{1}$ chain to be associated with recurrence-free survival, but in an opposite way (downregulated in patients with the probability of relapse). However, those results were not confirmed following validation by haptoglobin phenotyping of a 6-fold larger sample set $(\mathrm{n}=371)$.

Besides serum or plasma, nipple aspirate fluids and ductal lavage fluids collected from cancer and noncancer patients have been compared [86-88]. In nipple aspirate fluids, the protein profiles were heterogeneous among different patients, whereas the similarity between nipple aspirate fluids from cancerous and normal contralateral breast from a given patient was surprisingly high. However, some protein peaks were found to be differentially expressed between cancer and noncancer samples, some of them being correlated with axillary node involvement and the extent of the disease [89].

SELDI-based profiling approaches have also been applied to breast tissues for identifying proteins differentially expressed between normal and cancer cells or tissues [51, 90-92]. Four studies have examined the prognostic value of SELDI-based protein profiling in breast cancer samples. Ricolleau et al. [93] analyzed protein cytosolic extracts from 60 node-negative early breast cancers; they found high levels of ubiquitin and/or low levels of ferritin light chain to be associated with a good prog- to be differentially expressed between basal and luminal cell lines. A protein with an $\mathrm{m} / \mathrm{z}$ ratio 8,445 , which was downregulated in basal breast cancer, was found to correspond to C-terminus-truncated ubiquitin [adapted from 95].

nosis. These data were verified by immunohistochemistry and Western blot. Another study examined laser-microdissected invasive breast cancer cells and identified 2 proteins whose expression correlated with lymph node involvement. Interestingly, one of them (with low expression in node-positive disease) had an $\mathrm{m} / \mathrm{z}$ ratio of $8.5 \mathrm{kDa}$, consistent with ubiquitin [94]. We have recently profiled the cytosol of 27 human breast cancer cell lines [95]. Comparison of basal and luminal cell lines - as defined by genomics - generated a list of potential biomarkers. The MALDI-based approach identified ubiquitin as upregulated in 'luminal-like' cells (fig. 2). Interestingly, the peak corresponded to a posttranslational alteration of ubiquitin (namely, C-terminal truncation, which was demonstrated by differential enzymatic digestion followed MALDI-TOF MS measurements of the obtained peptides), rather than the full-length form. This was further validated in a small-sized sample of frozen luminal or basal breast cancers, suggesting the clinical pertinence of this information. In the same protein list, we identified S100A9 as a potential basal biomarker, in agreement with the presence of the corresponding gene in the transcriptionally defined basal gene cluster. Further validation came from immunohistochemistry on a large tissue microarray of early breast cancers: we showed that S100A9 expression was associated with other basal markers and shorter survival. Recently, a study profiled protein lysates from 105 breast cancers using IMAC-Cooper ProteinChip arrays and SELDI-based analysis [59]. When protein pro- 
Table 2. Main MALDI- and SELDI-TOF MS protein-profiling studies with independent validation

\begin{tabular}{|c|c|c|c|c|c|c|c|c|}
\hline Objectives & Ref. & \multicolumn{3}{|c|}{ Learning phase } & Ref. & \multicolumn{3}{|l|}{ Validation phase } \\
\hline \multirow{3}{*}{ Diagnosis } & {$[76]$} & serum & $\begin{array}{l}\text { invasive BC vs. HC } \\
\text { (155 vs. 155) }\end{array}$ & SELDI & {$[76]$} & serum (55 vs. 55$)$ & SELDI & NA \\
\hline & \multirow{2}{*}[96]{} & \multirow{2}{*}{ serum } & \multirow{2}{*}{$\begin{array}{l}\text { BC vs. } \mathrm{HC} \text { and } \mathrm{BD} \\
(103 \text { vs. } 41 \text { vs. } 25)\end{array}$} & \multirow{2}{*}{ SELDI } & {$[97]$} & $\begin{array}{l}\text { serum } \\
\text { ( } 49 \mathrm{BC} \text { vs. } 13 \mathrm{HC} \text { vs. } 27 \mathrm{BD} \text { ) }\end{array}$ & SELDI & \multirow{2}{*}{$\begin{array}{l}\text { up-regulation of C3a des-R } \\
\text { anaphylatoxin; } \\
\text { downregulation of ITIH4 }\end{array}$} \\
\hline & & & & & {$[98]$} & serum ( $48 \mathrm{BC}$ vs. $48 \mathrm{HC}$ ) & SELDI & \\
\hline
\end{tabular}

LCM = Laser capture microdissected; $\mathrm{BC}=$ breast cancer; $\mathrm{NB}=$ normal breast; $\mathrm{HC}=$ healthy control; FFPE = formalin-fixed paraffin-embedded; TMA $=$ tissue microarrays.

files obtained by SELDI were subjected to an unsupervised hierarchical clustering procedure, different groups of breast cancer were identified, and correlated with tumor type, nuclear grade and expression of hormonal receptors, mucin 1 and cytokeratins 5/6 or 14 . These tumor groups closely resembled luminal $\mathrm{A}$ and $\mathrm{B}$, basal and HER2-like carcinomas. Some discriminating proteins were identified, including annexin V and HSP27. Altogether, these results suggest that SELDI profiling of breast carcinomas identifies clinically relevant groups of patients similar to those previously defined by genomics.

Although some of them have been considered promising, the results from SELDI- or MALDI-based protein profiling have mostly been disappointing. Very few candidate protein peaks have been structurally identified yet and even fewer have been validated in large, independent series, as illustrated in table 2. For fluid-based approaches, the candidate markers that have been identified constitute normal cellular proteins and highly abundant blood proteins involved in coagulation and acute-phase response, indicating a general lack of tumor specificity [99]. In fact, as tumor-specific proteins are expected to be among the least abundant proteins, they could be below the detection limit of conventional SELDI- and MALDIbased methods, but could be revealed by more innovative MS-based devices or additional prefractionation meth- ods. Thus, SELDI- or MALDI-based protein profiling of biological fluids without additional preprocessing methods must now be considered as largely infraoptimal for biomarker discovery; other, more recent technologies should be deployed.

\section{Discussion and Perspectives}

This retrospective survey of pioneering retrospective studies shows that proteomics represents a promising domain of research in the diagnosis and prognosis of breast cancer. The potential biomarkers identified, consisting of a single or several proteins, represent a bar code signature of the phenotype of interest. Of course, whether they are directly associated with the phenotype in a biological sense or reflect another associated phenomenon remains to be explored. Due to their preliminary nature, the reported results raise some criticisms and highlight challenges that should be addressed in the near future to allow proteomics to reach its optimal yield and translate into tangible benefits for patients.

The sample size is relatively small and the results must be validated, refined and extended in larger series. In this context, immunohistochemistry on tissue microarrays is the most interesting approach, provided that the appro- 
priate antibody is available or can be made. As shown in table 2 , only a few studies have seen their results validated in independent series, and there is no consistency of data between studies. Several aspects may explain such discrepancies. There is great interstudy heterogeneity regarding patient populations (histoclinical features, treatment and follow-up), the primary end-point of prognostic studies and the method of analysis of survival (either as a dichotomous variable but with different cut-offs, or as a continuous variable). Other sources of heterogeneity are technological, with the use of different technological platforms, different protein sets and different methods of data analysis. Combined with the heterogeneity of breast cancer, all these differences may explain the discrepant results reported in some studies. As shown in table 2, only a few studies have included an independent validation set - although crucial in high-throughput analyses due to the risk of 'overfitting' [100] - and multivariate analyses testing the predictive independence of the biomarker when compared with classical histoclinical features. Finally, no molecular target, identified in poor-prognosis patients that could provide an alternative therapeutic solution, has clearly emerged as yet.

Several challenges will have to be addressed in the future. The accessibility, more or less restricted to some companies and academic facilities during the past years, is increasing rapidly, and the availability, complexity and cost of other proteomics tools will likely improve with the next-generation tools. A major challenge appears to lie in the complexity and enormity of the proteome and its dynamic state as well as the molecular complexity of breast cancer. Although being an extremely rapidly moving field of technological innovations, proteomics approaches still have to achieve some qualitative revolutions before identifying biomarkers that will reach routine clinical application. Even though current MS-based approaches are increasingly sensitive, they are still failing to achieve large access to low-abundance proteomes in complex biological samples such as serum or plasma. However, low-abundance proteins - within the microgram/milliliter range - likely represent many of the potential tumor-specific biomarkers. This limitation is essentially due to the high dynamic range of techniques, precluding simultaneous measurement of protein quantities that differ by a factor of up to $10^{10}$. Strategies aiming to overcome this drawback have been developed based on depletion/enrichment of a subset of the sample proteome [101], equalization [102, 103], or subfractionation for analyzing, for example, the phosphoproteome, glycoproteome or subcellular locations [104, 105]. As observed with all 'omics' tools, the handling of data for multiprotein experiments is a major bottleneck. Progress needs to be accomplished for producing, storing, analyzing, visualizing and interpreting data, and previous work on gene profiling data constitutes a precious base [106]. Efforts are also required to make results publicly available. This will facilitate not only external validation of results and meta-analyses, but also the development of analytics tools.

Another major issue is the all too pressing urge to have a high-quality sample bank (tumors and fluids) linked to a searchable database containing all histoclinical parameters of tumors as well as documenting patient consent and ensuring confidentiality. The careful and uniform collection of samples and data should become a component of all future clinical trials. As proteins are very sensitive to degradation, it is crucial to guarantee the quality of biological sampling and storage in carefully designed prospective collections.

Technological improvements are ongoing that may allow MS-based tools to be applied to formalin-fixed paraffin-embedded tissues [107, 108], which still constitute the main source of tumor material in pathological depositories. The amount of material required for experiments is another important issue because of the small size of clinical specimens and the absence of techniques for amplification of proteins. Improvements in microtechniques and nanotechnologies may soon provide ways to circumvent this obstacle.

Another ongoing major challenge is to develop kits that can simultaneously extract DNA, RNA and proteins from frozen samples.

Finally, it is clear that data from proteomics must be combined with data from other 'omics' approaches in an attempt to investigate mechanistic pathways in more detail as well as providing diagnostic or prognostic information in the clinical setting. This may represent a novel field of application of systems biology in order to combine multiple sources of data (e.g. genomics, proteomics and metabolomics) into a single unified hypothesis to explain and/or shed light on the biological processes involved in oncogenesis.

\section{Conclusion}

Clinical proteomics of breast cancer is still in its infancy and remains in the research field. Even if promising results have been reported, there has been no breakthrough that is close to becoming clinically applicable. A 
number of putative diagnostic and prognostic markers or signatures have been found, but their use in the clinical routine is premature, and no new targeted therapy has yet emerged. There is no doubt that many other potential markers will be identified in the next years. The challenge will be to perform correctly designed large retrospective studies including independent validation sets, followed by prospective validation studies to demonstrate the clinical benefits for patients. Even if a number of issues remain to be addressed before proteomics can enter clinical practice, it is anticipated that in the future such a promising approach will affect the current generation of physicians in charge of breast cancer patients.
It is too early to define the format of the proteomic tool that will be applied in clinical practice. One example includes protein arrays that combine quantitative and functional information, by detecting the activation of kinases or signaling pathways to be targeted by specific antitumor therapies. Characterization of discriminator proteins will provide new markers for screening, diagnosis, prognosis and follow-up, and will help developing new molecularly targeted anticancer drugs. Faced with the complexity of cancer proteomics and its great clinical potential, a global coordination of ongoing efforts appears to be crucial.

\section{References}

1 Bertucci F, Finetti P, Cervera N, Maraninchi D, Viens P, Birnbaum D: Gene expression profiling and clinical outcome in breast cancer. OMICS 2006;10:429-443.

-2 Sotiriou C, Pusztai L: Gene-expression signatures in breast cancer. N Engl J Med 2009; 360:790-800

3 Cardoso F, Van't Veer L, Rutgers E, Loi S, Mook S, Piccart-Gebhart MJ: Clinical application of the 70-gene profile: the MINDAC trial. J Clin Oncol 2008;26:729-735.

4 Sparano JA, Paik S: Development of the 21gene assay and its application in clinical practice and clinical trials. J Clin Oncol 2008;26:721-728.

5 Harris L, Fritsche H, Mennel R, Norton L, Ravdin P, Taube S, Somerfield MR, Hayes DF, Bast RC Jr: American Society of Clinical Oncology 2007 update of Recommendations for the use of tumor markers in breast cancer. J Clin Oncol 2007;25:5287-5312.

6 Anderson L, Seilhamer J: A comparison of selected mRNA and protein abundances in human liver. Electrophoresis 1997; 18:533537.

7 Ginestier C, Charafe-Jauffret E, Bertucci F, Eisinger F, Geneix J, Bechlian D, Conte N, Adelaide J, Toiron Y, Nguyen C, Viens P, Mozziconacci MJ, Houlgatte R, Birnbaum D, Jacquemier J: Distinct and complementary information provided by use of tissue and DNA microarrays in the study of breast tumor markers. Am J Pathol 2002;161:12231233.

8 Gygi SP, Rochon Y, Franza BR, Aebersold R: Correlation between protein and mRNA abundance in yeast. Mol Cell Biol 1999;19: $1720-1730$

-9 Tyers M, Mann M: From genomics to proteomics. Nature 2003;422:193-197.
10 Brennan DJ, Kelly C, Rexhepaj E, Dervan PA, Duffy MJ, Gallagher WM: Contribution of DNA and tissue microarray technology to the identification and validation of biomarkers and personalised medicine in breast cancer. Cancer Genomics Proteomics 2007;4: 121-134.

11 Haab BB: Antibody arrays in cancer research. Mol Cell Proteomics 2005;4:377-383.

12 Hudelist G, Pacher-Zavisin M, Singer CF, Holper T, Kubista E, Schreiber M, Manavi M, Bilban M, Czerwenka K: Use of highthroughput protein array for profiling of differentially expressed proteins in normal and malignant breast tissue. Breast Cancer Res Treat 2004;86:281-291.

13 Celis JE, Moreira JMA, Cabezon T, Gromov P, Friis E, Rank F, Gromova I: Identification of extracellular and intracellular signaling components of the mammary adipose tissue and its interstitial fluid in high risk breast cancer patients: toward dissecting the molecular circuitry of epithelial-adipocyte stromal cell interactions. Mol Cell Proteomics 2005;4:492-522.

14 Woodbury RL, Varnum SM, Zangar RC: Elevated HGF levels in sera from breast cancer patients detected using a protein microarray ELISA. J Proteome Res 2002;1:233-237.

15 Lin Y, Huang R, Chen L, Li S, Shi Q, Jordan C, Huang RP: Identification of interleukin-8 as estrogen receptor-regulated factor involved in breast cancer invasion and angiogenesis by protein arrays. Int J Cancer 2004; 109:507-515.

16 Vazquez-Martin A, Colomer R, Menendez JA: Protein array technology to detect HER2 (erbB-2)-induced 'cytokine signature' in breast cancer. Eur J Cancer 2007;43:11171124 .
17 Carlsson A, Wingren C, Ingvarsson J, Ellmark P, Baldertorp B, Ferno M, Olsson H, Borrebaeck CA: Serum proteome profiling of metastatic breast cancer using recombinant antibody microarrays. Eur J Cancer 2008;44:472-480.

18 Keyes K, Cox K, Treadway P, Mann L, Shih C, Faul MM, Teicher BA: An in vitro tumor model: analysis of angiogenic factor expression after chemotherapy. Cancer Res 2002; 62:5597-5602.

19 Dehqanzada ZA, Storrer CE, Hueman MT, Foley RJ, Harris KA, Jama YH, Shriver CD, Ponniah S, Peoples GE: Assessing serum cytokine profiles in breast cancer patients receiving a HER2/neu vaccine using Luminex technology. Oncol Rep 2007;17:687-694.

20 Nolen BM, Marks JR, Ta'san S, Rand A, Luong TM, Wang Y, Blackwell K, Lokshin AE: Serum biomarker profiles and response to neoadjuvant chemotherapy for locally advanced breast cancer. Breast Cancer Res 2008; 10:R45.

21 Kim BK, Lee JW, Park PJ, Shin YS, Lee WY, Lee KA, Ye S, Hyun H, Kang KN, Yeo D, Kim Y, Ohn SY, Noh DY, Kim CW: The multiplex bead array approach to identifying serum biomarkers associated with breast cancer. Breast Cancer Res 2009;11:R22.

22 Liotta LA, Espina V, Mehta AI, Calvert V, Rosenblatt K, Geho D, Munson PJ, Young L, Wulfkuhle J, Petricoin EF 3rd: Protein microarrays: meeting analytical challenges for clinical applications. Cancer Cell 2003;3: 317-325.

23 Rapkiewicz A, Espina V, Zujewski JA, Lebowitz PF, Filie A, Wulfkuhle J, Camphausen K, Petricoin EF 3rd, Liotta LA, Abati A: The needle in the haystack: application of breast fine-needle aspirate samples to quantitative protein microarray technology. Cancer 2007;111:173-184. 
-24 Boyd ZS, Wu QJ, O’Brien C, Spoerke J, Savage H, Fielder PJ, Amler L, Yan Y, Lackner MR: Proteomic analysis of breast cancer molecular subtypes and biomarkers of response to targeted kinase inhibitors using reversephase protein microarrays. Mol Cancer Ther 2008;7:3695-3706.

-25 Stemke-Hale K, Gonzalez-Angulo AM, Lluch A, Neve RM, Kuo WL, Davies M, Carey M, Hu Z, Guan Y, Sahin A, Symmans WF, Pusztai L, Nolden LK, Horlings H, Berns K, Hung MC, van de Vijver MJ, Valero V, Gray JW, Bernards R, Mills GB, Hennessy BT: An integrative genomic and proteomic analysis of PIK3CA, PTEN, and AKT mutations in breast cancer. Cancer Res 2008;68:60846091.

-26 Vandermoere F, El Yazidi-Belkoura I, Demont Y, Slomianny C, Antol J, Lemoine J, Hondermarck H: Proteomics exploration reveals that actin is a signaling target of the kinase Akt. Mol Cell Proteomics 2007;6:114124.

-27 Vandermoere F, El Yazidi-Belkoura I, Slomianny C, Demont Y, Bidaux G, Adriaenssens E, Lemoine J, Hondermarck $\mathrm{H}$ : The valosin-containing protein (VCP) is a target of Akt signaling required for cell survival. J Biol Chem 2006;281:14307-14313.

-28 Agarwal R, Gonzalez-Angulo AM, Myhre S, Carey M, Lee JS, Overgaard J, Alsner J, Stemke-Hale K, Lluch A, Neve RM, Kuo WL, Sorlie T, Sahin A, Valero V, Keyomarsi K, Gray JW, Borresen-Dale AL, Mills GB, Hennessy BT: Integrative analysis of cyclin protein levels identifies cyclin b1 as a classifier and predictor of outcomes in breast cancer. Clin Cancer Res 2009;15:3654-3662.

-29 Stults JT, Arnott D: Proteomics. Methods Enzymol 2005;402:245-289.

-30 Wilm M, Shevchenko A, Houthaeve T, Breit S, Schweigerer L, Fotsis T, Mann M: Femtomole sequencing of proteins from polyacrylamide gels by nano-electrospray mass spectrometry. Nature 1996;379:466-469.

- 31 Nesvizhskii AI, Vitek O, Aebersold R: Analysis and validation of proteomic data generated by tandem mass spectrometry. Nat Methods 2007;4:787-797.

- 32 O'Farrell PH: High resolution two-dimensional electrophoresis of proteins. J Biol Chem 1975;250:4007-4021.

- 33 Bergman AC, Benjamin T, Alaiya A, Waltham M, Sakaguchi K, Franzen B, Linder S, Bergman T, Auer G, Appella E, Wirth PJ, Jornvall $\mathrm{H}$ : Identification of gel-separated tumor marker proteins by mass spectrometry. Electrophoresis 2000;21:679-686.

-34 Bini L, Magi B, Marzocchi B, Arcuri F, Tripodi S, Cintorino M, Sanchez JC, Frutiger S, Hughes G, Pallini V, Hochstrasser DF, Tosi P: Protein expression profiles in human breast ductal carcinoma and histologically normal tissue. Electrophoresis $1997 ; 18$ : 2832-2841.
5 Franzen B, Auer G, Alaiya AA, Eriksson E, Uryu K, Hirano T, Okuzawa K, Kato $\mathrm{H}$, Linder S: Assessment of homogeneity in polypeptide expression in breast carcinomas shows widely variable expression in highly malignant tumors. Int J Cancer 1996;69: 408-414.

6 Franzen B, Linder S, Alaiya AA, Eriksson E, Uruy K, Hirano T, Okuzawa K, Auer G: Analysis of polypeptide expression in benign and malignant human breast lesions: downregulation of cytokeratins. Br J Cancer 1996; 74:1632-1638.

37 Hondermarck H, Vercoutter-Edouart AS, Revillion F, Lemoine J, el-Yazidi-Belkoura I, Nurcombe V, Peyrat JP: Proteomics of breast cancer for marker discovery and signal pathway profiling. Proteomics 2001;1:1216-1232.

38 Somiari RI, Somiari S, Russell S, Shriver CD: Proteomics of breast carcinoma. J Chromatogr B Analyt Technol Biomed Life Sci 2005;815:215-225.

39 Vercoutter-Edouart AS, Lemoine J, Le Bourhis X, Louis H, Boilly B, Nurcombe V, Revillion F, Peyrat JP, Hondermarck H: Proteomic analysis reveals that $14-3-3 \sigma$ is downregulated in human breast cancer cells. Cancer Res 2001;61:76-80.

40 Wulfkuhle JD, McLean KC, Paweletz CP, Sgroi DC, Trock BJ, Steeg PS, Petricoin EF 3rd: New approaches to proteomic analysis of breast cancer. Proteomics 2001;1:12051215.

41 Wulfkuhle JD, Sgroi DC, Krutzsch H, McLean K, McGarvey K, Knowlton M, Chen S, Shu H, Sahin A, Kurek R, Wallwiener D, Merino MJ, Petricoin EF 3rd, Zhao Y, Steeg PS: Proteomics of human breast ductal carcinoma in situ. Cancer Res 2002;62:67406749.

42 Jung EJ, Moon HG, Cho BI, Jeong CY, Joo YT, Lee YJ, Hong SC, Choi SK, Ha WS, Kim JW, Lee CW, Lee JS, Park ST: Galectin-1 expression in cancer-associated stromal cells correlates tumor invasiveness and tumor progression in breast cancer. Int J Cancer 2007; 120:2331-2338

-43 Alexander H, Stegner AL, Wagner-Mann C, $\mathrm{Du}$ Bois GC, Alexander S, Sauter ER: Proteomic analysis to identify breast cancer biomarkers in nipple aspirate fluid. Clin Cancer Res 2004;10:7500-7510.

44 Goufman EI, Moshkovskii SA, Tikhonova OV, Lokhov PG, Zgoda VG, Serebryakova MV, Toropygin IY, Vlasova MA, Safarova MR, Makarov OV, Archakov AI: Two-dimensional electrophoretic proteome study of serum thermostable fraction from patients with various tumor conditions. Biochemistry (Mosc) 2006;71:354-360.

45 Bloom GC, Eschrich S, Zhou JX, Coppola D, Yeatman TJ: Elucidation of a protein signature discriminating six common types of adenocarcinoma. Int J Cancer 2007;120:769775 .
46 Niméus E, Malmström J, Johnsson A, Marko-Varga G, Fernö M: Proteomic analysis identifies candidate proteins associated with distant recurrences in breast cancer after adjuvant chemotherapy. J Pharm Biomed Anal 2007;43:1086-1093.

-47 Vydra J, Selicharova I, Smutna K, Sanda M, Matouskova E, Bursikova E, Prchalova M, Velenska Z, Coufal D, Jiracek J: Two-dimensional electrophoretic comparison of metastatic and non-metastatic human breast tumors using in vitro cultured epithelial cells derived from the cancer tissues. BMC Cancer 2008;8:107.

48 LiJ, Gromov P, Gromova I, Moreira JM, Timmermans-Wielenga V, Rank F, Wang K, Li S, Li H, Wiuf C, Yang H, Zhang X, Bolund L, Celis JE: Omics-based profiling of carcinoma of the breast and matched regional lymph node metastasis. Proteomics 2008;8:50385052.

-49 Unlu M, Morgan ME, Minden JS: Difference gel electrophoresis: a single gel method for detecting changes in protein extracts. Electrophoresis 1997;18:2071-2077.

50 Bartkowiak K, Wieczorek M, Buck F, Harder S, Moldenhauer J, Effenberger KE, Pantel K, Peter-Katalinic J, Brandt BH: Two-dimensional differential gel electrophoresis of a cell line derived from a breast cancer micrometastasis revealed a stem/progenitor cell protein profile. J Proteome Res 2009;8:20042014.

-51 Traub F, Feist H, Kreipe HH, Pich A: SELDIMS-based expression profiling of ductal invasive and lobular invasive human breast carcinomas. Pathol Res Pract 2005;201:763770 .

52 Washburn MP, Ulaszek R, Deciu C, Schieltz DM, Yates JR 3rd: Analysis of quantitative proteomic data generated via multidimensional protein identification technology. Anal Chem 2002;74:1650-1657.

53 Jessani N, Niessen S, Wei BQ, Nicolau M, Humphrey M, Ji Y, Han W, Noh DY, Yates JR 3rd, Jeffrey SS, Cravatt BF: A streamlined platform for high-content functional proteomics of primary human specimens. Nat Methods 2005;2:691-697.

54 Gygi SP, Rist B, Gerber SA, Turecek F, Gelb $\mathrm{MH}$, Aebersold R: Quantitative analysis of complex protein mixtures using isotopecoded affinity tags. Nat Biotechnol 1999;17: 994-999.

55 Pawlik T, Hawke D, Liu Y, Krishnamurthy S, Fritsche H, Hunt K, Kuerer H: Proteomic analysis of nipple aspirate fluid from women with early-stage breast cancer using isotopecoded affinity tags and tandem mass spectrometry reveals differential expression of vitamin $\mathrm{D}$ binding protein. BMC Cancer 2006;6:68. 
56 Leth-Larsen R, Lund R, Hansen HV, Laenkholm AV, Tarin D, Jensen ON, Ditzel HJ: Metastasis-related plasma membrane proteins of human breast cancer cells identified by comparative quantitative mass spectrometry. Mol Cell Proteomics 2009;8:1436-1449.

57 Garbis SD, Tyritzis SI, Roumeliotis T, Zerefos P, Giannopoulou EG, Vlahou A, Kossida S, Diaz J, Vourekas S, Tamvakopoulos C, Pavlakis K, Sanoudou D, Constantinides CA: Search for potential markers for prostate cancer diagnosis, prognosis and treatment in clinical tissue specimens using amine-specific isobaric tagging (iTRAQ) with two-dimensional liquid chromatography and tandem mass spectrometry. J Proteome Res 2008;7:3146-3158.

58 Chen Y, Choong LY, Lin Q, Philp R, Wong $\mathrm{CH}$, Ang BK, Tan YL, Loh MC, Hew CL, Shah N, Druker BJ, Chong PK, Lim YP: Differential expression of novel tyrosine kinase substrates during breast cancer development. Mol Cell Proteomics 2007;6:20722087.

59 Brozkova K, Budinska E, Bouchal P, Hernychova L, Knoflickova D, Valik D, Vyzula R, Vojtesek B, Nenutil R: Surface-enhanced laser desorption/ionization time-of-flight proteomic profiling of breast carcinomas identifies clinicopathologically relevant groups of patients similar to previously defined clusters from cDNA expression. Breast Cancer Res 2008;10:R48.

60 Brancia FL: Recent developments in ion-trap mass spectrometry and related technologies. Expert Rev Proteomics 2006;3:143-151.

-61 Smith IC, Heys SD, Hutcheon AW, Miller ID, Payne S, Gilbert FJ, Ah-See AK, Eremin O, Walker LG, Sarkar TK, Eggleton SP, Ogston KN: Neoadjuvant chemotherapy in breast cancer: significantly enhanced response with docetaxel. J Clin Oncol 2002;20:14561466.

-62 Umar A, Kang H, Timmermans AM, Look MP, Meijer-van Gelder ME, den Bakker MA, Jaitly N, Martens JW, Luider TM, Foekens JA, Pasa-Tolic L: Identification of a putative protein profile associated with tamoxifen therapy resistance in breast cancer. Mol Cell Proteomics 2009;8:1278-1294.

-63 Solassol J, Marin P, Maudelonde T, Mange A: Proteomic profiling: the potential of SeldiTof for the identification of new cancer biomarkers (in French). Bull Cancer 2005;92: 763-768.

64 Issaq HJ, Veenstra TD, Conrads TP, Felschow D: The SELDI-TOF MS approach to proteomics: protein profiling and biomarker identification. Biochem Biophys Res Commun 2002;292:587-592.

65 Clarke CH, Buckley JA, Fung ET: SELDITOF-MS proteomics of breast cancer. Clin Chem Lab Med 2005;43:1314-1320.
66 Koopmann J, Zhang Z, White N, Rosenzweig J, Fedarko N, Jagannath S, Canto MI, Yeo CJ, Chan DW, Goggins M: Serum diagnosis of pancreatic adenocarcinoma using surfaceenhanced laser desorption and ionization mass spectrometry. Clin Cancer Res 2004; 10:860-868.

67 Kozak KR, Amneus MW, Pusey SM, Su F, Luong MN, Luong SA, Reddy ST, Farias-Eisner R: Identification of biomarkers for ovarian cancer using strong anion-exchange ProteinChips: potential use in diagnosis and prognosis. Proc Natl Acad Sci USA 2003; 100 : 12343-12348.

68 Petricoin EF, Ardekani AM, Hitt BA, Levine PJ, Fusaro VA, Steinberg SM, Mills GB, Simone C, Fishman DA, Kohn EC, Liotta LA: Use of proteomic patterns in serum to identify ovarian cancer. Lancet 2002;359:572577.

69 Petricoin EF III, Ornstein DK, Paweletz CP, Ardekani A, Hackett PS, Hitt BA, Velassco A, Trucco C, Wiegand L, Wood K, Simone CB, Levine PJ, Linehan WM, Emmert-Buck MR, Steinberg SM, Kohn EC, Liotta LA: Serum proteomic patterns for detection of prostate cancer. J Natl Cancer Inst 2002;94: 1576-1578.

70 Won Y, Song HJ, Kang TW, Kim JJ, Han BD, Lee SW: Pattern analysis of serum proteome distinguishes renal cell carcinoma from other urologic diseases and healthy persons. Proteomics 2003;3:2310-2316.

71 Zhang Z, Bast RC Jr, Yu Y, Li J, Sokoll LJ, Rai AJ, Rosenzweig JM, Cameron B, Wang YY, Meng X-Y, Berchuck A, van Haaften-Day C, Hacker NF, de Bruijn HWA, van der Zee AGJ, Jacobs IJ, Fung ET, Chan DW: Three biomarkers identified from serum proteomic analysis for the detection of early stage ovarian cancer. Cancer Res 2004;64: 5882-5890.

72 Gast MC, van Dulken EJ, van Loenen TK, Kingma-Vegter F, Westerga J, Flohil CC, Knol JC, Jimenez CR, van Gils CH, Wessels LF, Schellens JH, Beijnen JH: Detection of breast cancer by surface-enhanced laser desorption/ionization time-of-flight mass spectrometry tissue and serum protein profiling. Int J Biol Markers 2009;24:130-141.

73 Gast MC, Van Gils CH, Wessels LF, Harris N, Bonfrer JM, Rutgers EJ, Schellens JH, Beijnen JH: Serum protein profiling for diagnosis of breast cancer using SELDI-TOF MS. Oncol Rep 2009;22:205-213.

74 Vlahou A, Laronga C, Wilson L, Gregory B, Fournier K, McGaughey D, Perry RR, Wright GL Jr, Semmes OJ: A novel approach toward development of a rapid blood test for breast cancer. Clin Breast Cancer 2003;4:203-209.

5 Gast MC, Bonfrer JM, van Dulken EJ, de Kock L, Rutgers EJ, Schellens JH, Beijnen JH: SELDI-TOF MS serum protein profiles in breast cancer: assessment of robustness and validity. Cancer Biomark 2006;2:235-248.
6 Belluco C, Petricoin EF, Mammano E, Facchiano F, Ross-Rucker S, Nitti D, Di Maggio C, Liu C, Lise M, Liotta LA, Whiteley G: Serum proteomic analysis identifies a highly sensitive and specific discriminatory pattern in stage 1 breast cancer. Ann Surg Oncol 2007;14:2470-2476.

77 Li J, Orlandi R, White CN, Rosenzweig J, Zhao J, Seregni E, Morelli D, Yu Y, Meng XY, Zhang Z, Davidson NE, Fung ET, Chan DW: Independent validation of candidate breast cancer serum biomarkers identified by mass spectrometry. Clin Chem 2005;51:22292235.

78 Song J, Patel M, Rosenzweig CN, Chan-Li Y, Sokoll LJ, Fung ET, Choi-Miura NH, Goggins M, Chan DW, Zhang Z: Quantification of fragments of human serum inter-alphatrypsin inhibitor heavy chain 4 by a surfaceenhanced laser desorption/ionization-based immunoassay. Clin Chem 2006;52:10451053.

79 Villanueva J, Martorella AJ, Lawlor K, Philip J, Fleisher M, Robbins RJ, Tempst P: Serum peptidome patterns that distinguish metastatic thyroid carcinoma from cancer-free controls are unbiased by gender and age. $\mathrm{Mol}$ Cell Proteomics 2006;5:1840-1852.

80 Fung ET, Yip TT, Lomas L, Wang Z, Yip C, Meng XY, Lin S, Zhang F, Zhang Z, Chan DW, Weinberger SR: Classification of cancer types by measuring variants of host response proteins using SELDI serum assays. Int $\mathrm{J}$ Cancer 2005; 115:783-789.

81 Shi Q, Harris LN, Lu X, Li X, Hwang J, Gentleman R, Iglehart JD, Miron A: Declining plasma fibrinogen alpha fragment identifies HER2-positive breast cancer patients and reverts to normal levels after surgery. J. Proteome Res 2006;5:2947-2955.

82 Becker S, Cazares LH, Watson P, Lynch H, Semmes OJ, Drake RR, Laronga C: Surfacedenhanced laser desorption/ionization timeof-flight (SELDI-TOF) differentiation of serum protein profiles of BRCA-1 and sporadic breast cancer. Ann Surg Oncol 2004;11:907-914.

83 Gast MC, Schellens JH, Beijnen JH: Clinical proteomics in breast cancer: a review. Breast Cancer Res Treat 2009;116:17-29.

84 Goncalves A, Esterni B, Bertucci F, Sauvan R, Chabannon C, Cubizolles M: Postoperative serum proteomic profiles may predict metastatic relapse in high-risk primary breast cancer patients receiving adjuvant chemotherapy. Oncogene 2006;25:981-989.

85 Gast MC, van Tinteren H, Bontenbal M, van Hoesel RQ, Nooij MA, Rodenhuis S, Span PN, Tjan-Heijnen VC, de Vries EG, Harris N, Twisk JW, Schellens JH, Beijnen JH: Haptoglobin phenotype is not a predictor of recurrence free survival in high-risk primary breast cancer patients. BMC Cancer 2008;8: 389. 
86 Paweletz CP, Trock B, Pennanen M, Tsangaris T, Magnant C, Liotta LA, Petricoin EF 3rd: Proteomic patterns of nipple aspirate fluids obtained by SELDI-TOF: potential for new biomarkers to aid in the diagnosis of breast cancer. Dis Markers 2001;17:301-307.

- 87 Pawlik TM, Fritsche H, Coombes KR, Xiao L, Krishnamurthy S, Hunt KK, Pusztai L, Chen JN, Clarke CH, Arun B, Hung MC, Kuerer HM: Significant differences in nipple aspirate fluid protein expression between healthy women and those with breast cancer demonstrated by time-of-flight mass spectrometry. Breast Cancer Res Treat 2005;89: 149-157.

88 Noble JL, Dua RS, Coulton GR, Isacke CM, Gui GP: A comparative proteinomic analysis of nipple aspiration fluid from healthy women and women with breast cancer. Eur J Cancer 2007;43:2315-2320.

89 Kuerer HM, Coombes KR, Chen JN, Xiao L, Clarke C, Fritsche H, Krishnamurthy S, Marcy S, Hung MC, Hunt KK: Association between ductal fluid proteomic expression profiles and the presence of lymph node metastases in women with breast cancer. Surgery 2004;136:1061-1069.

90 Cowherd SM, Espina VA, Petricoin EF 3rd, Liotta LA: Proteomic analysis of human breast cancer tissue with laser-capture microdissection and reverse-phase protein $\mathrm{mi}$ croarrays. Clin Breast Cancer 2004;5:385392.

-91 Sanders ME, Dias EC, Xu BJ, Mobley JA, Billheimer D, Roder H, Grigorieva J, Dowsett M, Arteaga CL, Caprioli RM: Differentiating proteomic biomarkers in breast cancer by laser capture microdissection and MALDI MS. J Proteome Res 2008;7:1500-1507.

92 Umar A, Dalebout JC, Timmermans AM, Foekens JA, Luider TM: Method optimisation for peptide profiling of microdissected breast carcinoma tissue by matrix-assisted laser desorption/ionisation-time of flight and matrix-assisted laser desorption/ionisation-time of flight/time of flight-mass spectrometry. Proteomics 2005;5:2680-2688.
93 Ricolleau G, Charbonnel C, Lode L, Loussouarn D, Joalland MP, Bogumil R, Jourdain S, Minvielle S, Campone M, DeporteFety R, Campion L, Jezequel P: Surface-enhanced laser desorption/ionization time of flight mass spectrometry protein profiling identifies ubiquitin and ferritin light chain as prognostic biomarkers in node-negative breast cancer tumors. Proteomics 2006;6: 1963-1975.

94 Nakagawa T, Huang SK, Martinez SR, Tran AN, Elashoff D, Ye X, Turner RR, Giuliano AE, Hoon DS: Proteomic profiling of primary breast cancer predicts axillary lymph node metastasis. Cancer Res 2006;66:1182511830.

95 Goncalves A, Charafe-Jauffret E, Bertucci F, Audebert S, Toiron Y, Esterni B, Monville F, Tarpin C, Jacquemier J, Houvenaeghel G, Chabannon C, Extra JM, Viens P, Borg JP, Birnbaum D: Protein profiling of human breast tumor cells identifies novel biomarkers associated with molecular subtypes. Mol Cell Proteomics 2008;7:1420-1433.

96 Li J, Zhang Z, Rosenzweig J, Wang YY, Chan DW: Proteomics and bioinformatics approaches for identification of serum biomarkers to detect breast cancer. Clin Chem 2002;48:1296-1304.

97 Mathelin C, Cromer A, Wendling C, Tomasetto C, Rio MC: Serum biomarkers for detection of breast cancers: a prospective study. Breast Cancer Res Treat 2006;96:83-90.

98 van Winden A, Gast M-C, Beijnen J, Rutgers E, Grobbee D, Peeters P, van Gils C: Validation of previously identified serum biomarkers for breast cancer with SELDI-TOF MS: a case control study. BMC Med Genomics 2009;2:4.
99 Diamandis EP: Analysis of serum proteomic patterns for early cancer diagnosis: drawing attention to potential problems. J Natl Cancer Inst 2004;96:353-356.

100 Quackenbush J: Microarray analysis and tumor classification. N Engl J Med 2006; 354:2463-2472.

101 Echan LA, Tang HY, Ali-Khan N, Lee K, Speicher DW: Depletion of multiple highabundance proteins improves protein profiling capacities of human serum and plasma. Proteomics 2005;5:3292-3303.

102 Castagna A, Cecconi D, Sennels L, Rappsilber J, Guerrier L, Fortis F, Boschetti E, Lomas L, Righetti PG: Exploring the hidden human urinary proteome via ligand library beads. J Proteome Res 2005;4:1917-1930.

103 Guerrier L, Thulasiraman V, Castagna A, Fortis F, Lin S, Lomas L, Righetti PG, Boschetti E: Reducing protein concentration range of biological samples using solidphase ligand libraries. J Chromatogr B Analyt Technol Biomed Life Sci 2006;833:3340.

104 Mann M, Jensen ON: Proteomic analysis of post-translational modifications. Nat Biotechnol 2003;21:255-261.

105 Zhang W, Zhou G, Zhao Y, White MA, Zhao Y: Affinity enrichment of plasma membrane for proteomics analysis. Electrophoresis 2003;24:2855-2863.

106 Ermolaeva O, Rastogi M, Pruitt KD, Schuler GD, Bittner ML, Chen Y, Simon R, Meltzer P, Trent JM, Boguski MS: Data management and analysis for gene expression arrays. Nat Genet 1998;20:19-23.

107 Bellet V, Boissière F, Bibeau F, Desmetz C, Berthe M, Rochaix P, Maudelonde T, Mange A, Solassol J: Proteomic analysis of RCL2 paraffin-embedded tissues. J Cell Mol Med 2007, Epub ahead of print.

108 Lemaire R, Desmons A, Tabet JC, Day R, Salzet M, Fournier I: Direct analysis and MALDI imaging of formalin-fixed, paraffin-embedded tissue sections. J Proteome Res 2007;6:1295-1305. 